IZA DP No. 4161

Population Aging, Elderly Migration and Education Spending: Intergenerational Conflict Revisited

Mehmet Serkan Tosun

Claudia R. Williamson

Pavel Yakovlev

May 2009 


\title{
Population Aging, Elderly Migration and Education Spending: Intergenerational Conflict Revisited
}

\author{
Mehmet Serkan Tosun \\ University of Nevada, Reno \\ and IZA \\ Claudia R. Williamson \\ Appalachian State University \\ Pavel Yakovlev \\ Duquesne University
}

Discussion Paper No. 4161

May 2009

IZA

P.O. Box 7240

53072 Bonn

Germany

Phone: +49-228-3894-0

Fax: +49-228-3894-180

E-mail: iza@iza.org

Any opinions expressed here are those of the author(s) and not those of IZA. Research published in this series may include views on policy, but the institute itself takes no institutional policy positions.

The Institute for the Study of Labor (IZA) in Bonn is a local and virtual international research center and a place of communication between science, politics and business. IZA is an independent nonprofit organization supported by Deutsche Post Foundation. The center is associated with the University of Bonn and offers a stimulating research environment through its international network, workshops and conferences, data service, project support, research visits and doctoral program. IZA engages in (i) original and internationally competitive research in all fields of labor economics, (ii) development of policy concepts, and (iii) dissemination of research results and concepts to the interested public.

IZA Discussion Papers often represent preliminary work and are circulated to encourage discussion. Citation of such a paper should account for its provisional character. A revised version may be available directly from the author. 


\section{ABSTRACT}

\section{Population Aging, Elderly Migration and Education Spending: Intergenerational Conflict Revisited ${ }^{*}$}

Elderly have been increasingly targeted as a group to enhance economic development and the tax base in communities. While recent literature on elderly migration tends to focus on how elderly migration patterns are influenced by state fiscal variables, the reverse effect from elderly population on fiscal variables is very plausible. This paper reexamines the intergenerational conflict in education financing using U.S. state and county level data. We analyze how preferences for education spending might vary across different elderly age groups, an analysis that has not been explored before. We estimate the impact of elderly population and elderly migration rates on education spending using panel data and spatial econometric techniques. Our results broadly support the presence of intergenerational conflict and age heterogeneity in preferences for education spending among elderly migrants.

JEL Classification: H75, R23

Keywords: population aging, elderly migration, education spending, intergenerational conflict

Corresponding author:

Mehmet Serkan Tosun

Department of Economics

College of Business

University of Nevada, Reno

Mail Stop 0030

Reno, NV 89557

USA

E-mail: tosun@unr.edu

\footnotetext{
* We gratefully acknowledge the funding support from McDonough Foundation and Becker Fund for Economic Development Research. We also want to thank Karen Conway and Jonathan Rork for their helpful comments, Justin Ross for assistance with spatial econometrics, and Arzu Sen for superb help with collecting and managing the data.
} 


\section{Introduction}

Retirees are becoming increasingly important for state and local economies and budgets. While retirees pose significant fiscal challenges to state and local governments, they may also offer opportunities to enhance local economic development. A major factor in the rise of their importance is the rapid increase in the number of retired elderly in the U.S. population and its fiscal and economic implications. An important consequence of population aging is increasing fiscal pressure to spend on social security, health care, and other welfare programs that benefit the elderly at the expense of other programs that benefit the young. Population aging can affect spending on education through the enhanced political power of the elderly as a voting group. Slavov (2006) demonstrates that government expenditures tend to be biased in favor the elderly because they are easier to sustain politically across a broad class of majoritarian institutions due to asymmetric distribution of benefits that generate broad political support for large transfers to older individuals. Since education is a major input to human capital accumulation, aging can have a significant negative impact on future economic growth. Recent studies by Gradstein and Kaganovich (2004), Holtz-Eakin, Lovely and Tosun (2004), Tosun (2005), Tosun (2008) as well as Razin, Sadka, and Swagel (2002) examine the growth implications of the intergenerational conflict in education spending, but lead to different conclusions and warrant empirical investigation.

This study presents new evidence on the relationship between education spending and population aging building on the original finding by James Poterba (1997) that state K-12 education spending is negatively related by the share of retirees in state population. Poterba (1998) argues that the link between population aging and public education is theoretically ambiguous and has to be resolved empirically, but the empirical consensus has not yet emerged. For instance, Ladd and Murray (2001) do not find any evidence in support of intergenerational 
conflict in education spending at the county level, while Harris et al. (2001) do find such evidence in school district data. While some studies argue and present evidence that the elderly have a strong dislike for education spending (Brunori, 2003; Button, 1992 and Reeder and Glasgow, 1990), others do not find strong evidence of such relationship (Rosenbaum and Button, 1989; Button and Rosenbaum, 1989). By examining the voting behavior in tax referenda in six Florida counties, for instance, Button (1992) concludes that intergenerational conflict is very prevalent in education-related issues. On the other hand, Deller and Walzer (1993) find a much weaker evidence of such generational conflict in a survey of residents in rural Illinois by showing that retirees support local education spending, albeit at a lower level than non-retirees. Moreover, the 2004 AARP Aging American Voter Survey indicates that a strong majority of older people support federal government’s responsibility in educating young people. ${ }^{1}$

The lack of empirical consensus on the intergenerational conflict may be the result of complications created by reverse or simultaneous causality where the elderly can influence government policy and also be influenced by it in their migration decisions. ${ }^{2}$ Farnham and Sevak (2002) provide evidence from the Health and Retirement Study (HRS) that households move to areas with lower per pupil expenditures and reduce their property tax liability by $\$ 115$ on average. Newbold (1996) investigates the determinants of elderly interstate migration from 1985 to 1990 and finds that onward migrants are more sensitive to physical amenities than Medicare expenditures, for example. Gale and Heath (2000) find that elderly prefer states where wage earners carry more of the burden in financing publicly provided goods. On the other hand, Conway and Rork $(2004,2006)$ find that elderly migration is likely to cause or influence changes

\footnotetext{
${ }^{1}$ However, the survey did not have a similar question for state and local governments. The same survey shows that a large group of older people became more conservative in issues such as bureaucracy and taxes. See AARP (2004) for a summary of findings from this survey.

${ }^{2}$ Studies by Cebula (1990), Conway and Houtenville (1998, 2001), Conway and Rork (2004, 2006), and Farnham and Sevak (2002) explore these reverse causality issues.
} 
in state tax policy rather than be influenced by them. Similarly, Voss et al. (1988) determine that state “death” taxes do not contributed to elderly out-migration.

The empirical evidence on the intergenerational conflict is further complicated by the fact that it is not only the size of the elderly population but also their migration patterns and age heterogeneity in preferences that could have different implications for education spending. According to the U.S. Census report by He and Schachter (2003) on migration patterns of the elderly between 1995 and 2000, the mobility of older population differ significantly by age, sex and region. For example, the young old (people 65 to 74 years old) were more likely to move to a different state compared to the older old, particularly the oldest old (people 85 years and over). In addition the population 55 to 64 years old had mobility patterns similar to the young old group (people 65 to 74 years old). Hence, it is particularly useful to examine the migration effects of this near retirement group (some already retired) in addition to the older age groups as we do in this paper.

By addressing the problem of reverse causality, differentiating between migration and the share of elderly population, and controlling for age heterogeneity in preferences, this study aims to provide more authoritative evidence on the intergenerational conflict first examined by Poterba (1997). We use Conway and Rork’s (2006) panel-data approach in addressing the reverse causality problem that complicates the estimation of the relationship between state fiscal policy and elderly migration. In addition to using a longitudinal panel of the U.S. states, we also test for the presence of intergenerational conflict using county-level data and find similar evidence. Controlling for spatial autocorrelation at the county level, we also show how the effect of retiree migration on education spending varies across different age groups of retirees.

The paper is structured as follows. The next section briefly discusses possible taxing and spending changes amid elderly in-migration. The paper then discusses the empirical strategy and 
methodology in section 3. Section 4 presents results from state and county level regressions. The last section contains our concluding remarks.

\section{Rising Old-Age Dependency and Preferred Taxing and Spending}

One important consequence of substantial elderly in-migration is the increasing political power of the elderly. Table 1 gives an overview of the political weight of elderly as a voting group using voting statistics compiled by the U.S. Census Bureau. The age group 18 to 24 had the fewest registered voters (38.2 percent) and the least number to vote (17.2 percent), in 2002. With an increase in age, the percentage registered and voted also increased. Sixty-one percent over eighteen years of age were registered to vote and 42.3 percent actually voted in 2002. Age groups below 45 years of age fell below this average in both categories. However, in the 45 to 54 years category there are 67.4 percent registered and 50.2 percent voted. The largest percent registered was in the 75 to 84 age category with 76.9 percent, and this group also had the second highest turnout with 61.9 percent voting in 2002. The 65 to 74 age category had the highest voting percentage with 63.1 percent.

To illustrate the possible impact of the political power of the elderly on education spending, one can use a median voter model within an overlapping generations growth model. At

each period of the model, a cohort of size $N_{t}$ is born. Then total population in each period is $N_{t-1}+N_{t}$ where $N_{t}=\left(1+\eta_{t}\right) N_{t-1}$ and $\eta_{t}$ is the population growth rate at period $t$. Given this, the median voter is defined by

$$
N_{t-1}+N_{t} \int_{0}^{m} f(a) d a=\frac{N_{t-1}+N_{t}}{2}
$$

where $a$ is the ability and $m$ is the ability level of the median voter. This in turn can be used to show 


$$
\frac{d m}{d \eta_{t}}=\frac{2}{F^{\prime}(m) 4\left(1+\eta_{t}\right)^{2}},
$$

which is positive under a uniform ability distribution. With more elderly in the population, the median voter becomes a person with lower ability and the preferred tax rate and education spending of the median voter is lower. The intuition behind this is as follows: as the elderly population increases through in-migration, old-age dependency ratio rises and older people will need fewer young voters to form a majority. These young voters are the ones at the lower end of the ability distribution. They prefer lower taxes and spending than higher ability counterparts because their return from public education is lower. While we don't discuss the other aspects of the model, Tosun (2003), Holtz-Eakin, Lovely and Tosun (2004) and Tosun (2008) show that this political economy effect is weighed against the growth effect which exerts a reverse positive pressure on the government spending on education through a positive income elasticity of government spending. Hence, in an overlapping-generations growth model with a political process for taxation and education spending, the effect of elderly migrants on education spending is ambiguous and must be resolved empirically.

\section{Empirical Methodology}

In this section, we examine the empirical evidence on the intergenerational conflict in education financing and expand previous empirical methodology to account for elderly migration and spatial dependence. We follow Poterba's (1997) basic empirical model specification for the state and county level regressions, but we improve upon Poterba's analysis by utilizing panel data and spatial econometric techniques. In addition, we are able to examine richer elderly migration data at the county level due to available data for several elderly age groups from 55 years old and over. We use Poterba’s (1997) basic empirical model specification for the state level regressions: 


$$
\begin{aligned}
& \mathrm{ED} / \mathrm{CHILD}_{i t}=\beta_{0}+\beta_{1} Y_{i t}+\beta_{2} \mathrm{KID}_{i t}+\beta_{3} \mathrm{OLD}_{i t}+\beta_{4} \mathrm{OWNERS}_{i t} \\
& +\beta_{5} \text { NONWHITE }_{i t}+\beta_{6} \text { URBAN }_{i t}+\beta_{7} \text { INMIG65 }_{i t}+\beta_{8} \text { OUTMIG65 }_{i t}+\varepsilon_{i t}
\end{aligned}
$$

Where ED/CHILD is the logarithm of per pupil government spending on $\mathrm{K}-12$ education, $\mathrm{Y}$ is the logarithm of real state per capita personal income, KID is the logarithm of the state population shares aged 0 to 15 , OLD is the logarithm of the state population shares aged 65 and over, OWNERS is the logarithm of the population share that owns homes, NONWHITE is the logarithm of the population share that is nonwhite, and URBAN is the logarithm of the population share that lives in urban areas. ${ }^{3}$ We extend Poterba's (1997) basic model to include the logarithms of in-migration and out-migration rates for people 65 years old and over (INMIG65 and OUTMIG65, respectively). These variables are calculated as total in-migrants or out-migrants divided by total state population in a given year. Our state dataset is a balanced panel that includes observations for each state (except for Alaska and Hawaii) in years 1970, 1980, 1990, and 2000 amounting to 192 observations in total. Nominal values of per capita personal income and education spending per pupil are deflated using GDP deflator obtained from the Bureau of Economic Analysis. Tables 2 and 3 provide the descriptive statistics for the state and county level data used in our regressions. Table 4 gives the data sources and web links for the data.

Due to significant correlation between KID, OLD, and Y variables at the state level, their coefficient estimates are likely to be biased and difficult to infer from. Moreover, Conway and Rork (2006) find evidence suggesting that elderly migration determines state tax policy and not the other way around. For this and other reasons, we believe that elderly migration variables are better suited than elderly population shares for capturing the effect of intergenerational competition on education spending. Thus, we reexamine the intergenerational conflict by

\footnotetext{
${ }^{3}$ Due to the data availability constraints, our database omits the federal aid and poverty variables used in Poterba's (1997) regressions. Also, our KID variable is different from Poterba's variable defined as the logarithms of the state
} 
including elderly migration rates in both state and county regressions. Like Poterba (1997), we expect the OWNERS variable to capture the after-tax price of education spending and the URBAN variable to capture the differences in the cost of delivering school services as a function of the spatial distribution of population or potential taste differences for public spending between urban and rural residents. Poterba (1997) points out the difficulty of interpreting the coefficient for NONWHITE because it may proxy not only for the racial mix effect on education spending but also for higher moments of the income distribution.

We use the same basic econometric model as shown in equation (3) in our county level regressions as well. However, there are a few important differences about the county dataset that are worth mentioning. Unlike the state dataset, the county dataset is just a cross-section of counties from 48 continental United States and the District of Columbia where all variables are the same as in the state dataset except for a more detailed age-group breakdown of elderly migration rates. Our elderly migrants are grouped in the following age categories: 55-64, 65-74, $75-84$, and 85 and older. Our elderly in and out migration rates are calculated as in-migration or out-migration flows during 1995-2000 divided by county population in 1995 and come from the Census 2000 PUMS dataset. By using migration data prior to 2003, we hope to eliminate the simultaneous causality problem between education spending and migration. The county dataset has at least two advantages over the state dataset. With 2957 observations, it is significantly larger than the state dataset containing only 192 observations. Plus, our county dataset contains migration variables for four distinct age groups. We believe that the biggest advantage of the county dataset is its ability to examine the heterogeneity of preferences for education across different elderly age groups, which is probably the most novel aspect of this paper. The countylevel analysis has its challenges as well as its benefits. In Poterba's (1997, p.5) own words: and Ramsey specification tests) and our findings resemble those of Poterba. 
One drawback of analyzing state-level data on spending and demographics is that many of the critical decisions on spending levels are made by voters in local jurisdictions. State average spending levels therefore conceal substantial heterogeneity within states. Studying local jurisdictions brings a different set of empirical problems, because the demographic composition of a small community cannot be viewed as exogenous, but rather depends on the structure of local public spending. This can make it impossible to generalize from the local level relationship between demographic structure and spending patterns to broader based changes.

We attempt to address a number of challenging econometric issues in our state and county level regressions. In addition to examining the heterogeneity of preferences for education spending across age groups, we improve upon earlier studies by subjecting our estimates to a variety of advanced econometric techniques at different levels of aggregation (i.e. state vs. county). To account for the potential influence of state-specific and time-specific factors and omitted variables on our estimates, we use state and time fixed effects modeled as $\varepsilon_{i t}=\delta_{i}+\tau_{t}+\sigma_{i t}$. We also utilize a number of econometric techniques that address potential autocorrelation, heteroskedasticity, endogeneity, outlier, and spatial dependence issues that could make empirical estimates biased and inconsistent.

Spatial dependence is a serious concern in the type of data that involve interstate (or intercounty) comparisons. Cliff and Ord (1981) and Anselin (1988) pioneered these models to control for any direct influence of spatial neighbors, spillover effects, and externalities generated between cross-sectional observations. Failing to address spatial dependence may lead to biased, inefficient, and/or inconsistent coefficient estimates. Elhorst (2003) explains in detail the panel data spatial error and spatial lag models. ${ }^{4}$ Spatial dependence is likely to be present in situations when states, for example, engage in some form of "yardstick" competition in taxation or government spending on highways, healthcare, education, and other public services and infrastructure. States are often forced to compete for businesses and migrants in their quest for greater economic wealth and better standards of living. Much of the research on interstate competition has focused on taxation and to a much lesser extent, unfortunately, on government 
spending. ${ }^{5}$ Yet, the limited number of existing studies on interstate competition in public services finds that states increase their spending on education, highways, healthcare, and welfare in response to spending increases by their neighbors. ${ }^{6}$ Given Case, Hines and Rosen's (1993) finding of strategic spatial interaction in education spending between neighboring states, we argue that Poterba’s (1997) basic econometric model shown in equation (3) should be augmented with spatial effects. States or counties that engage in some sort of "copycat" behavior (a la Baicker 2005) or "yardstick" competition in education spending would be better characterized by a spatial lag model in which each state (county) spending depends on spending by its neighbors. Equation (4) features the spatial lag or spatial autoregressive model (SAM) specification that uses maximum likelihood (ML) estimation of the spatial lag component without which the ordinary least squares (OLS) estimates for $\beta$ would be biased and inconsistent.

$$
\begin{aligned}
& \mathrm{ED} / \mathrm{CHILD}_{\mathrm{it}}=\beta_{0}+\rho W\left(\mathrm{ED} / \mathrm{CHILD}_{\mathrm{it}}\right)+\beta_{1} Y_{i t}+\beta_{2} \mathrm{KID}_{i t}+\beta_{3} \mathrm{OLD}_{i t}+\beta_{4} \mathrm{OWNERS}_{i t} \\
& +\beta_{5} \mathrm{NONWHITE}_{i t}+\beta_{6} \mathrm{URBAN}_{i t}+\beta_{7} \mathrm{INMIG65}_{i t}+\beta_{8} \mathrm{OUTMIG65}_{i t}+\varepsilon_{i t}
\end{aligned}
$$

Where $W$ is the spatial weight (contiguity) matrix, $\rho$ is the spatial dependence coefficient, and $W\left(E D / C H I L D_{i t}\right)$ is a spatially lagged explanatory variable.

A different type of spatial dependence could also be present in the relationship we are trying to estimate. Spatial dependence that occurs due to spatially correlated omitted variables, spatially correlated aggregate variables or spatially correlated errors in variable measurements is different from spatially lag dependence and should be modeled accordingly. Equation (5)

\footnotetext{
${ }^{4}$ We use MATLAB routines of spatial error model (SEM), spatial autoregressive model (SAR), and spatial Durbin model (SDM) which can be downloaded from LeSage's web site www.spatial-econometrics.com.

${ }^{5}$ For studies on interstate tax competition see Case (1993), Heyndels and Vuchelen (1998), Brueckner and Saavedra (2001), Buettner 2001, Revelli (2001), Rork (2003), and Conway and Rork (2004).

${ }^{6}$ Figlio et al. (1999), Saavedra (2000), and Baicker (2005) find evidence of competition in state spending on health and public welfare, while Case, Hines and Rosen (1993) find evidence of competition in aggregate as well as specific state expenditures on education, health care, and highways. On the contrary, Bruce et al. (2006) find evidence suggesting that states free-ride on positive spillover from infrastructure improvements by other states, which leads to a negative response to an increase in a neighbor's spending on infrastructure.
} 
features the spatial error model (SEM) specification that uses ML estimation of the spatial error term without which the OLS estimates of $\beta$ would be inefficient.

$$
\begin{aligned}
& \mathrm{ED} / \mathrm{CHILD}_{\text {it }}=\beta_{0}+\beta_{1} Y_{i t}+\beta_{2} \mathrm{KID}_{i t}+\beta_{3} \mathrm{OLD}_{i t}+\beta_{4} \mathrm{OWNERS}_{i t} \\
& +\beta_{5} \mathrm{NONWHITE}_{i t}+\beta_{6} \mathrm{URBAN}_{i t}+\beta_{7} \mathrm{INMIG65}_{i t}+\beta_{8} \mathrm{OUTMIG65}_{i t}+\varepsilon_{i t}
\end{aligned}
$$

All the variables here are as previously defined except for $\varepsilon_{i t}$, which now equals to $\lambda W \varepsilon_{i t}+u_{i t}$, where $W$ is the spatial weight (contiguity) matrix, $\lambda$ is the spatial dependence coefficient, and $u$ is a vector of homoskedastic errors. We use a row-standardized contiguity matrix computed from latitude and longitude coordinates of geographic neighbors. In a row-standardized matrix the rows sum up to one and allows the spatial effects to be interpreted as the change in the "average" neighbor. Both spatial error (SEM) and spatial autoregressive lag (SAM) models are going to be estimated at the state and county levels via maximum likelihood. The next section presents our findings.

\section{Empirical Results}

First, we present our state-level regression results, which are then followed by county-level results. Shown in Table 5 are our empirical estimates of the determinants of state K-12 education spending. The first (basic) OLS regression in Table 5 shows that higher real per capita income, homeownership rate, and share of population under 15 are positively and significantly related to education spending per pupil, while share of nonwhite population is negatively and significantly related to education spending per pupil. Although the coefficients for per capita income, homeownership, and nonwhite population have the expected signs, the coefficient for population under 15 does not, albeit being significantly different from zero only at 90\% confidence level. Moreover, the coefficient for population 65 and over is positive, but not significantly different

from zero. These results are not consistent with either the intergenerational conflict or Poterba's 
(1997) findings. As discussed previously, the estimates for these variables could be biased and inconsistent due to being significantly correlated with each other (see the correlation matrix in Table 6). Therefore, we argue that migration variables can be better suited for examining the intergenerational conflict. In fact, the first OLS regression in Table 5 yields the expected negative and statistically significant coefficient for in-migration rate for population 65 years old and over plus the expected positive and statistically significant coefficient for out-migration rate for population 65 years old and over. According to these estimates, an inflow of elderly migrants lowers, and outflow of elderly migrants raises, state K-12 education spending per pupil. These estimates are supportive of the intergenerational conflict presence in education financing. To provide robustness, we use several different estimation techniques. ${ }^{7}$

The second OLS regression in Table 5 incorporates two-way (state and time) fixed effects, which are preferred to a random effects regression as suggested by the Hausman test we performed. The two-way fixed effects OLS regression yields the expected signs for per capita income, population under 15 and over 65, and nonwhite population. However, the coefficients for population under 15 and over 65 are not significantly different from zero and the coefficient estimate for the elderly in-migration rate is now unexpectedly positive and statistically significant, while out-migration rate is positive and significant as expected. While the second (two-way fixed effects) regression improves upon the first one in terms of explanatory power, its estimates are likely to suffer from panel level heteroskedasticity and autocorrelation problems. We address these issues by specifying a panel specific heteroskedastic and first-order autoregressive error structure in the next regression (FGLS with two-way fixed effects) in Table 5. The FGLS estimates, however, do not improve dramatically over the second OLS estimates and reveal the existence of the "same-sign" problem for the in and out migration rates, which

\footnotetext{
${ }^{7}$ We perform link and Ramsey RESET tests of omitted variable bias and find that the basic model specification for the state level regression in Equation 13 was not rejected by both of these tests at the $95 \%$ confidence level.
} 
should have the opposite signs according to the intergeneration conflict theory. The "same-sign" problem is not unique to our paper and has plagued past elderly migration studies such as Serow et al. (1986), Fournier et al. (1988), Conway and Houtenville (2001, 2003), and more recently Conway and Rork (2006).

We attempt to address the "same-sign" problem in our next regression. This problem could be the result of the endogeneity bias. It could be argued that state fiscal policies that are favorable towards retirees, such as lower K-12 education spending, can induce more elderly migration that will be reflected in the share of elderly population. In turn, due to high rates of elderly electoral participation, retirees can have a significant influence on state fiscal policy in general and education spending in particular. This is analogous to the "which came first, chicken or the egg?” argument. Conway and Rork (2006) identify the same issue in their paper in which they argue that the percentage of elderly population could reflect past state tax policy and migration decisions. Like Conway and Rork (2006), we address this problem by using 10-year lags of elderly migration rates in the next FGLS regression. ${ }^{8}$ The second FGLS regression with two-way fixed effects (Table 5) and lagged migration rates yields the expected relationships between education spending and its determinants. Namely, per capita income, homeownership, and lagged elderly out-migration have a significant positive effect on K-12 education spending per pupil, while nonwhite population, population under 15 and over 65, and lagged elderly inmigration have a significant negative effect. Not only shares of population under 25 and over 65, but also in and out elderly migration rates have the expected signs and statistical significance in

\footnotetext{
${ }^{8}$ Although 10-year lags indicating the existence of 10-year relationships between migration rates and current education spending may appear to be far fetched, the fact that amenities, which are virtually fixed, rather than taxes (as found by Conway and Rork 2006) appear to be the most important determinants of migration should also give credence to their long run (10 and more years) determination of migration patterns and their effects on state policies. We also use more recent lags of migration rates in county regressions due to better data availability and find similar results.
} 
this regression. This evidence provides strong support for the existence of the intergenerational conflict in education financing. ${ }^{9}$

In the next two regressions, with two-way fixed effects, we address the detected spatial error and spatial lag effects that could potentially bias previous non-spatial regression estimates. We present the regression results from SAM and SEM models for comparison purposes in Table 5. Both SAM and SEM regressions indicate that there is significant spatial dependence of both types ( $\rho$ for spatial lag and $\lambda$ for spatial error). As can be seen in Table 5, SAM and SEM regressions yield very similar estimates for most variables, but some differences exist nevertheless. For instance, the SAM regression yields a negative coefficient for population over 65 (as expected), while the SEM regression yields a positive coefficient for the same variable. Both coefficient estimates are not significantly different from zero, however. The SEM regression also yields a negative and statistically significant (as expected) coefficient for the lagged elderly in-migration rate, while the SAM regression yields a negative but not statistically significant coefficient for the same variable. Finally, both SAM and SEM regressions yield a positive and significant coefficient for the lagged elderly out-migration rate. Although both SAM and SEM estimates appear to support the intergenerational conflict in education financing, we recommend using SAM for inference because it is more theoretically consistent with the intergenerational hypothesis examined in this paper and is favored over SEM by the Lagrange multiplier test.

In the next set of regressions (Table 7), we examine the effect of age heterogeneity in elderly migrants on 2003 education spending using county level data. We use in and out migration flows for the 1995-2000 period divided by 1995 county population for the following

\footnotetext{
${ }^{9}$ We also run a dynamic Arellano-Bond GMM regression where in and out elderly migration rates are treated as endogenous variables and are instrumented with their own lags. The Arellano-Bond GMM regression yields a negative and significant coefficient for in-migration variable and positive but insignificant coefficient for outmigration variable. These estimates agree with the intergenerational conflict in education financing argument.
} 
age groups: 55-64, 65-74, 75-84, 85 and older. A priori, we expect the 55-64 and 65-74 age groups to have similar preferences for education spending since these two groups appear to be similar in their migration (see Table 8) and retirement decisions. These two age groups are more likely to have grandchildren (or even children) who are in primary and secondary schools compared to the older age groups (75 and over). The older age groups may derive limited benefits from education and choose to directly not support education policy through voting or indirectly through fiscal pressure. Therefore, the in-migrants in 55-64 and 65-74 age groups may support education spending more relative to in-migrants in 75-84 and 85 and over age groups. We expect in-migrants to have a negative effect and out-migrants to have a positive effect but with variation in magnitude and significance across age groups. The expected overall effect of elderly migrants 65 years old and over is ambiguous due to the age heterogeneity in preferences for education among elderly migrants. The overall effect depends on the relative strength of each age group, which makes our county-level regressions complimentary to our state-level regressions. State level data can yield ambiguous results due to aggregation not addressing the issue of age heterogeneity in preferences for education spending among elderly migrants. ${ }^{10} \mathrm{We}$ also address the potential endogeneity bias in our county level regressions by using more recent data than in the state regressions lagged migration rates, which occur prior to the 2003 share of elderly population and education spending per pupil figures.

We estimate the spatial lag (SAM), spatial error (SEM), and spatial Durbin (SDM) models to determine which ones are going to produce the most reliable estimates to be ultimately reported. All three models produce generally similar estimates for the elderly migration variables and show the existence of significant spatial dependence. However, not all three models are equally suited for inference. The SDM model, for example, is prone to multicollinearity problem

\footnotetext{
${ }^{10}$ Poterba (1997) notes that cross-country data does not suggest an obvious relationship between the share of the elderly in the population and the share of government spending devoted to the elderly or to children.
} 
in our case. The SEM model, which is estimated via maximum likelihood in this paper, can mistakenly misinterpret the spatial lag component $\rho$ from the SAM model as the spatial error component $\lambda$ from the SEM model (Anselin 1988, LeSage 1999). The SEM model may also produce results that are significantly different from the bench mark OLS results if the specified model has some omitted variable bias, which is the common problem in virtually all empirical studies. In our case, the SEM, SAM, and OLS estimates are fairly similar with respect to the main variables of interest. Moreover, our Lagrange multiplier tests have shown a preference for the SAM model, which is more prevalent in other empirical studies and more theoretically consistent with the intergeneration conflict hypothesis. Hence, we consider our SAM estimates to be most suitable for inference and present only SAM estimates in Table 7 due to space limitations.

The first regression in Table 7 shows that in-migration of 55-64 year olds has a negative but insignificant effect on education county spending per pupil, while out-migration of 55-64 year olds has a positive and significant effect. This regression also shows that per capita income increases county education spending per pupil, while homeownership and urban population decrease it. Interestingly, population under 15 has a significant negative effect on education spending, but population over 65 has no statistically significant effect. The second regression in Table 7 shows the effect of elderly migrants ages 65 to 74 on education spending. This regression also shows that per capita income and out-migration of 65-74 year olds have a significant positive effect on education spending per pupil, while in-migration of 65-74 year olds, population under 15, homeownership, and urban population have a significant negative effect. The third regression featuring the migrants 75-85 years old shows similar results for all variables. It should be noted that the negative in migration effect and the positive out migration effect becomes much larger for this age group (elasticities of 6.5\% and 5.4\%, respectively). The 
next regression featuring the migrants $85+$ years yields the same large negative and statistically significant result for in migration while out-migration is positive but insignificant.

The last two regressions in Table 7 feature the average migration rates for $55+$ and $65+$ age groups. The results for the migrants 55 years old and over show that in-migration is negatively and significantly related to education spending, while out-migration is significantly and positively related to education spending per pupil. The results for the migrants 65 years old and over yield no surprises and show that in-migrating retirees in that age group, on average, reduce education spending per pupil and out migration increases education spending per pupil. Contrasting the magnitudes of the coefficients for in-migration and out-migration rates across these two groups show that support for education spending appears to decrease with age. This result suggests that as retirees become older they prefer less K-12 education spending than younger retirees, supporting heterogeneity of preferences for education spending among retirees.

Altogether, our empirical analysis at the state and county level reveals significant evidence supporting the presence of intergenerational conflict in the U.S. K-12 education financing. Namely, it appears that elderly migrants generally lead to a reduction in education spending in the areas they move to. These results persist regardless of whether the net inmigration or in and out migration rates are used in the regressions. However, we find that some control variables change their signs and significance levels across estimation techniques and datasets making their effects on education spending difficult to interpret. The negative coefficient for the homeownership rate, albeit being contrary to Poterba's (1997) estimates, makes sense if one views the estimated equation as the demand schedule for education and the homeownership rate (in Poterba’s own view) as the after-tax price of education. In other words, our results suggest an intuitive relationship: if the tax price of education rises, quantity demanded falls. The share of nonwhites in total population shows up consistently negative and often 
significant in our state level regressions, but is positive and insignificant in the county-level regressions. Finally, the negative coefficient for the share of urban residents in total population suggests that urban areas spend less on education perhaps due to economies of scale or lower transportation costs (which can account for a substantial portion of education expenditures).

\section{Concluding Remarks}

In this paper we reexamine intergenerational conflict in education financing using several advanced econometric techniques that are applied to U.S. state and county data on education spending and elderly migration. Our findings broadly support the existence of the intergenerational conflict in education spending and are robust to the existence of different forms of spatial dependence, heteroskedasticity, autocorrelation, outliers, endogeneity bias, fixed effects and random effects.

The state-level regression results support the intergenerational conflict in the U.S. education financing found by Poterba (1997) and other researchers. Using a balanced panel of 48 contiguous states for 1970,1980, 1990, and 2000, we show that states with higher share of elderly population and higher elderly migration experienced lower education spending per pupil. In the next set of regressions, we examine the impact of age heterogeneity among elderly migrants on education financing using county-level data. We find that in-migration of age groups 65 and older decreases education spending, but in-migration of people 75 years old and over decreases it at a much larger extent. The overall effect of retiree (65 years old and over) inmigration on education spending per pupil is negative and significant. Likewise, the outmigration of retirees (65 years old and over) has a positive effect on education spending per pupil that more than cancels out the negative in-migration effect. Our results also show that the magnitude of the negative effects on education spending from elderly in-migration and positive 
effects from elderly out-migration increase with age. These results broadly support the existence of a government failure where concentrated benefits shift towards the elderly due to migration patterns. 
Table 1: Voting Statistics in November 2002, Total U.S. (in thousands)

\begin{tabular}{lccccc} 
& \multicolumn{5}{c}{ (in thousands) } \\
\cline { 3 - 6 } Age & Total & Number Population & Percent & Reported Voted \\
Number & Percent \\
\hline 18 to 24 years & 27,377 & 10,470 & 38.2 & 4,697 & 17.2 \\
25 to 34 years & 38,512 & 19,339 & 50.2 & 10,450 & 27.1 \\
35 to 44 years & 43,716 & 26,214 & 60.0 & 17,569 & 40.2 \\
45 to 54 years & 40,043 & 27,006 & 67.4 & 20,088 & 50.2 \\
55 to 64 years & 26,881 & 19,424 & 72.3 & 15,432 & 57.4 \\
65 to 74 years & 17,967 & 13,681 & 76.1 & 11,339 & 63.1 \\
75 to 84 years & 12,287 & 9,446 & 76.9 & 7,600 & 61.9 \\
18 years and over & 210,421 & 128,154 & 60.9 & 88,903 & 42.3 \\
65 year and over & 30,254 & 23,127 & 76.4 & 18,939 & 62.6 \\
85 year and over & 3,640 & 2,573 & 70.7 & 1,729 & 47.5 \\
75 years and over & 15,925 & 12,020 & 75.5 & 9,328 & 58.6 \\
\hline
\end{tabular}

Source: U.S. Census Bureau, Current Population Survey, November 2002. 
Table 2: Summary Statistics for the Data Used in State Level Regressions

\begin{tabular}{lccc}
\hline & & & Standard \\
& Observations & Mean & Deviation \\
\hline Real education spending per pupil & 192 & 5,048 & 2,069 \\
Real per capita personal income & 192 & 20,630 & 6,279 \\
Share of population under 15 & 192 & 0.24 & 0.04 \\
Share of population 65 and over & 192 & 0.12 & 0.02 \\
Homeownership rate & 192 & 0.67 & 0.05 \\
Share of nonwhite population & 192 & 0.14 & 0.10 \\
Share of urban population & 192 & 0.68 & 0.15 \\
In-migration rate for population 65 and older & 192 & 0.06 & 0.05 \\
Out-migration rate for population 65 and older & 192 & 0.05 & 0.02 \\
\hline
\end{tabular}


Table 3: Summary Statistics for the Data Used in County Level Regressions

\begin{tabular}{lccc}
\hline & & & $\begin{array}{c}\text { Standard } \\
\text { Deviation }\end{array}$ \\
\hline Education spending per pupil & Observations & Mean & 2,158 \\
Per capita personal income & 2957 & 8,959 & 5,051 \\
Share of population under 15 & 2957 & 24,685 & 0.03 \\
Share of population over 65 & 2957 & 0.15 & 0.04 \\
Homeownership rate & 2957 & 0.75 & 0.07 \\
Share of nonwhite population & 2957 & 0.12 & 0.15 \\
Share of urban population & 2957 & 0.40 & 0.30 \\
In-migration rate for population 65 and older & 2957 & 0.0076 & 0.0067 \\
Out-migration rate for population 65 and older & 2957 & 0.0076 & 0.0068 \\
In-migration rate for population 55-64 years old & 2957 & 0.0072 & 0.0079 \\
Out-migration rate for population 55-64 years old & 2957 & 0.0051 & 0.0054 \\
In-migration rate for population 65-74 years old & 2957 & 0.0039 & 0.0040 \\
Out-migration rate for population 65-74 years old & 2957 & 0.0034 & 0.0034 \\
In-migration rate for population 75-84 years old & 2957 & 0.0023 & 0.0023 \\
Out-migration rate for population 75-84 years old & 2957 & 0.0027 & 0.0028 \\
In-migration rate for population 85 and older & 2957 & 0.0014 & 0.0015 \\
Out-migration rate for population 85 and older & 2957 & 0.0016 & 0.0021 \\
\hline
\end{tabular}


Table 4: Data Sources and Links

\begin{tabular}{|c|c|}
\hline Variables & Source \\
\hline $\begin{array}{l}\text { State education spending } \\
\text { per pupil }\end{array}$ & $\begin{array}{l}\text { United States Census Bureau: Statistical Abstracts of the United States } \\
\text { http://www.census.gov/prod/www/abs/statab.html }\end{array}$ \\
\hline $\begin{array}{l}\text { County education } \\
\text { spending per pupil }\end{array}$ & $\begin{array}{l}\text { United States Census Bureau: Public Education Finance Report } 2003 \\
\text { http://www.census.gov/govs/www/school03.html }\end{array}$ \\
\hline $\begin{array}{l}\text { State per capita personal } \\
\text { income }\end{array}$ & $\begin{array}{l}\text { Bureau of Economic Analysis } \\
\text { http://www.bea.gov/bea/regional/spi// }\end{array}$ \\
\hline $\begin{array}{l}\text { County per capita } \\
\text { personal income }\end{array}$ & $\begin{array}{l}\text { Bureau of Economic Analysis } \\
\text { http://www.bea.gov/bea/regional/reis/ }\end{array}$ \\
\hline All state population data & $\begin{array}{l}\text { United States Census Bureau: Statistical Abstracts } \\
\text { http://www.census.gov/prod/www/abs/statab.html }\end{array}$ \\
\hline $\begin{array}{l}\text { All county population } \\
\text { data }\end{array}$ & $\begin{array}{l}\text { United States Census Bureau: Population Estimates } \\
\text { http://www.census.gov/popest/estimates.php }\end{array}$ \\
\hline State homeownership rate & $\begin{array}{l}\text { United States Census Bureau: Housing and Household Economic } \\
\text { Statistics Division } \\
\text { http://www.census.gov/hhes/www/housing/census/historic/owner.html }\end{array}$ \\
\hline $\begin{array}{l}\text { County homeownership } \\
\text { rate }\end{array}$ & $\begin{array}{l}\text { United States Census Bureau: Population Estimates } \\
\text { http://www.census.gov/popest/housing/files/HU-EST2004-CO.csv }\end{array}$ \\
\hline $\begin{array}{l}\text { State elderly migration } \\
\text { rates }\end{array}$ & $\begin{array}{l}\text { United States Census Bureau: Statistical Abstracts } \\
\text { http://www.census.gov/prod/www/abs/statab.html }\end{array}$ \\
\hline $\begin{array}{l}\text { County elderly migration } \\
\text { rates }(1995-2000)\end{array}$ & au: 2000 PUMS \\
\hline
\end{tabular}


Table 5: Determinants of State K-12 Education Spending per Pupil

(Standard errors reported in parenthesis)

\begin{tabular}{|c|c|c|c|c|c|c|}
\hline Estimation & OLS & OLS & FGLS & FGLS & SAM & SEM \\
\hline $\begin{array}{l}\text { Two-way fixed } \\
\text { effects }\end{array}$ & - & Yes & Yes & Yes & Yes & Yes \\
\hline Constant & $\begin{array}{c}-3.435 * * * \\
(0.690)\end{array}$ & $\begin{array}{l}-0.991 * * * \\
(2.32)\end{array}$ & $\begin{array}{c}-3.017 * * * \\
(0.899)\end{array}$ & $\begin{array}{c}-2.791 * * * \\
(0.946)\end{array}$ & - & - \\
\hline $\begin{array}{l}\text { Real per capita } \\
\text { personal income }\end{array}$ & $\begin{array}{c}1.254^{* * *} \\
(0.076)\end{array}$ & $\begin{array}{c}0.782 * * * \\
(0.228)\end{array}$ & $\begin{array}{c}0.952 * * * \\
(0.095)\end{array}$ & $\begin{array}{c}0.836 * * * \\
(0.093)\end{array}$ & $\begin{array}{c}0.857 * * * \\
(0.087)\end{array}$ & $\begin{array}{c}1.100 * * * \\
(0.093)\end{array}$ \\
\hline $\begin{array}{l}\text { Share of population } \\
\text { under } 15\end{array}$ & $\begin{array}{l}0.015^{*} \\
(0.187)\end{array}$ & $\begin{array}{l}-0.955 \\
(0.372)\end{array}$ & $\begin{array}{l}-1.072 \\
(0.138)\end{array}$ & $\begin{array}{c}-1.777 * * * \\
(0.127)\end{array}$ & $\begin{array}{c}-1.581^{* * *} \\
(0.243)\end{array}$ & $\begin{array}{l}-1.680^{* * *} \\
(0.265)\end{array}$ \\
\hline $\begin{array}{l}\text { Share of population } \\
\text { over } 65\end{array}$ & $\begin{array}{c}0.199 \\
(0.086)\end{array}$ & $\begin{array}{l}-0.305 \\
(0.186)\end{array}$ & $\begin{array}{l}-0.269 \\
(0.079)\end{array}$ & $\begin{array}{c}-0.581 * * * \\
(0.086)\end{array}$ & $\begin{array}{l}-0.177 \\
(0.145)\end{array}$ & $\begin{array}{c}0.004 \\
(0.157)\end{array}$ \\
\hline $\begin{array}{l}\text { Homeownership } \\
\text { rate }\end{array}$ & $\begin{array}{l}0.092^{*} \\
(0.150)\end{array}$ & $\begin{array}{l}-0.126 \\
(0.423)\end{array}$ & $\begin{array}{l}-0.371 \\
(0.158)\end{array}$ & $\begin{array}{c}0.224 \\
(0.285)\end{array}$ & $\begin{array}{l}-1.210^{* * * *} \\
(0.427)\end{array}$ & $\begin{array}{c}-1.419^{* * *} \\
(0.462)\end{array}$ \\
\hline $\begin{array}{l}\text { Share of nonwhite } \\
\text { population }\end{array}$ & $\begin{array}{c}-0.008^{* * *} \\
(0.012)\end{array}$ & $\begin{array}{c}-0.063 * * * \\
(0.037)\end{array}$ & $\begin{array}{c}-0.051 * * * \\
(0.015)\end{array}$ & $\begin{array}{c}-0.048 * * \\
(0.021)\end{array}$ & $\begin{array}{l}-0.025 \\
(0.048)\end{array}$ & $\begin{array}{l}-0.003 \\
(0.057)\end{array}$ \\
\hline $\begin{array}{l}\text { Share of urban } \\
\text { population }\end{array}$ & $\begin{array}{l}-0.136 \\
(0.052)\end{array}$ & $\begin{array}{c}0.185 \\
(0.123)\end{array}$ & $\begin{array}{c}0.174 \\
(0.049)\end{array}$ & $\begin{array}{c}0.309^{* * *} \\
(0.044)\end{array}$ & $\begin{array}{c}0.368 * * * \\
(0.095)\end{array}$ & $\begin{array}{c}0.402^{* * *} \\
(0.100)\end{array}$ \\
\hline $\begin{array}{l}\text { In-migration rate, } \\
\text { population over } 65\end{array}$ & $\begin{array}{c}-0.034^{* * *} \\
(0.022)\end{array}$ & $\begin{array}{l}0.048^{* *} \\
(0.057)\end{array}$ & $\begin{array}{l}0.022^{* *} \\
(0.030)\end{array}$ & - & - & - \\
\hline $\begin{array}{l}\text { Out-migration rate, } \\
\text { population over } 65\end{array}$ & $\begin{array}{c}0.068^{* * *} \\
(0.043)\end{array}$ & $\begin{array}{l}0.071^{*} \\
(0.093)\end{array}$ & $\begin{array}{l}0.024^{*} \\
(0.038)\end{array}$ & - & - & - \\
\hline $\begin{array}{l}\text { Lag of in-migration } \\
\text { rate, population } \\
\text { over } 65\end{array}$ & - & - & - & $\begin{array}{c}-0.110 * * * \\
(0.041)\end{array}$ & $\begin{array}{l}-0.091 \\
(0.060)\end{array}$ & $\begin{array}{c}-0.125^{* *} \\
(0.062)\end{array}$ \\
\hline $\begin{array}{l}\text { Lag of out- } \\
\text { migration rate, } \\
\text { population over } 65\end{array}$ & - & - & - & $\begin{array}{c}0.299 * * * \\
(0.040)\end{array}$ & $\begin{array}{c}0.344 * * * \\
(0.071)\end{array}$ & $\begin{array}{c}0.348^{* * * *} \\
(0.076)\end{array}$ \\
\hline$\rho$ & - & - & - & - & $\begin{array}{c}0.227 * * * \\
(0.026)\end{array}$ & - \\
\hline$\lambda$ & - & - & - & - & - & $\begin{array}{c}0.263 * * * \\
(0.100)\end{array}$ \\
\hline $\mathrm{R}^{2}$ & 0.89 & 0.96 & - & - & 0.95 & 0.95 \\
\hline Observations & 192 & 192 & 192 & 144 & 144 & 144 \\
\hline \multicolumn{7}{|c|}{$\begin{array}{l}\text { Notes: Dependent variable: education spending per capita in real dollars. Significance level: *** at } 1 \%, * * \text { at } 5 \% \text {, * } \\
\text { at 10\%. The sample is a balanced panel of } 48 \text { continental United States (excluding Alaska and Hawaii) for the years } \\
1970,1980,1990 \text {, and } 2000 \text {. All variables are in logarithms. Robust standard errors are used to control for } \\
\text { heteroskedasticity. Robust and median regressions that are resistant to outlier bias show similar results. The } \\
\text { Hausman test rejected the random effects estimator in favor of the fixed effects estimator. In and out migration lags } \\
\text { are lagged in } 10 \text {-year intervals due to data availability. Both spatial lag (SAM) and spatial error (SEM) models are } \\
\text { estimated using maximum likelihood, where } \rho \text { and } \lambda \text { are spatial lag and spatial error components, respectively. } \\
\text { Using net in-migration rates instead of in and out migration rates yield similar results. }\end{array}$} \\
\hline
\end{tabular}


Table 6: Correlation Matrix for State Regression Variables

\begin{tabular}{|c|c|c|c|c|c|c|c|c|c|}
\hline & $\begin{array}{l}\text { Education } \\
\text { exp./pupil }\end{array}$ & Income & $\begin{array}{l}\text { Share of } \\
15 \text { and } \\
\text { younger }\end{array}$ & $\begin{array}{l}\text { Share of } \\
65 \text { and } \\
\text { older }\end{array}$ & Nonwhite & $\begin{array}{l}\text { Home } \\
\text { owner }\end{array}$ & Urban & $\begin{array}{l}\text { In- } \\
\text { migration } \\
65+\end{array}$ & $\begin{array}{l}\text { Out- } \\
\text { migration } \\
65+\end{array}$ \\
\hline Education exp./pupil & 1 & & & & & & & & \\
\hline Income & $0.9329 *$ & 1 & & & & & & & \\
\hline $\begin{array}{l}\text { Share of people } 15 \\
\text { and younger }\end{array}$ & $-0.7821 *$ & $-0.7953^{*}$ & 1 & & & & & & \\
\hline $\begin{array}{l}\text { Share of people } 65 \\
\text { and older }\end{array}$ & $0.5017 *$ & $0.4428 *$ & $-0.7082 *$ & 1 & & & & & \\
\hline Nonwhite & -0.0376 & -0.0897 & -0.021 & $0.2042 *$ & 1 & & & & \\
\hline Home owner & $0.2146 *$ & $0.2963^{*}$ & $-0.2511^{*}$ & -0.0359 & $-0.2121^{*}$ & 1 & & & \\
\hline Urban & $0.2290 *$ & $0.3470 *$ & -0.0704 & -0.072 & $-0.2646^{*}$ & $0.2679 *$ & 1 & & \\
\hline In-migration 65+ & 0.0052 & 0.0507 & -0.0496 & $-0.1669 *$ & 0.0039 & 0.0432 & $0.1448 *$ & 1 & \\
\hline Out-migration $65+$ & $0.2014^{*}$ & $0.2167 *$ & -0.0662 & $-0.1580 *$ & $-0.2336 *$ & $-0.1554 *$ & $0.1608 *$ & $0.5945^{*}$ & 1 \\
\hline
\end{tabular}


Table 7: Determinants of County K-12 Education Spending per Pupil

(Standard errors reported in parenthesis)

\begin{tabular}{|c|c|c|c|c|c|c|}
\hline Estimation & SAM & SAM & SAM & SAM & SAM & SAM \\
\hline Migration Ages & $55-64$ & $65-74$ & $75-84$ & $85+$ & $55+$ & $65+$ \\
\hline Constant & $\begin{array}{c}1.115 * * * \\
(0.172)\end{array}$ & $\begin{array}{c}1.099 * * * \\
(0.170)\end{array}$ & $\begin{array}{c}1.043 * * * \\
(0.167)\end{array}$ & $\begin{array}{c}1.058 * * * \\
(0.168)\end{array}$ & $\begin{array}{c}1.235^{* * *} \\
(0.179)\end{array}$ & $\begin{array}{c}1.089 * * * \\
(0.169)\end{array}$ \\
\hline $\begin{array}{l}\text { Per capita personal } \\
\text { income }\end{array}$ & $\begin{array}{c}0.122 * * * \\
(0.017)\end{array}$ & $\begin{array}{c}0.125^{* * * *} \\
(0.017)\end{array}$ & $\begin{array}{c}0.131^{* * * *} \\
(0.017)\end{array}$ & $\begin{array}{c}0.130 * * * \\
(0.017)\end{array}$ & $\begin{array}{c}0.121^{* * *} \\
(0.017)\end{array}$ & $\begin{array}{c}0.129 * * * \\
(0.017)\end{array}$ \\
\hline $\begin{array}{l}\text { Share of population } \\
\text { under } 15\end{array}$ & $\begin{array}{c}-0.177 * * * \\
(0.028)\end{array}$ & $\begin{array}{c}-0.175 * * * \\
(0.027)\end{array}$ & $\begin{array}{c}-0.173 * * * \\
(0.027)\end{array}$ & $\begin{array}{c}-0.171 * * * \\
(0.027)\end{array}$ & $\begin{array}{c}-0.193 * * * \\
(0.027)\end{array}$ & $\begin{array}{c}-0.179 * * * \\
(0.027)\end{array}$ \\
\hline $\begin{array}{l}\text { Share of population } \\
\text { over } 65\end{array}$ & $\begin{array}{l}-0.013 \\
(0.014)\end{array}$ & $\begin{array}{l}-0.014 \\
(0.014)\end{array}$ & $\begin{array}{l}-0.020 \\
(0.014)\end{array}$ & $\begin{array}{l}-0.011 \\
(0.015)\end{array}$ & $\begin{array}{l}-0.022 \\
(0.014)\end{array}$ & $\begin{array}{l}-0.018 \\
(0.015)\end{array}$ \\
\hline Homeownership rate & $\begin{array}{c}-0.185 * * * \\
(0.039)\end{array}$ & $\begin{array}{c}-0.187 * * * \\
(0.039)\end{array}$ & $\begin{array}{c}-0.182 * * * \\
(0.038)\end{array}$ & $\begin{array}{c}-0.197 * * * \\
(0.038)\end{array}$ & $\begin{array}{c}-0.151 * * * \\
(0.039)\end{array}$ & $\begin{array}{c}-0.176^{* * *} \\
(0.039)\end{array}$ \\
\hline $\begin{array}{l}\text { Share of nonwhite } \\
\text { population }\end{array}$ & $\begin{array}{c}0.002 \\
(0.002)\end{array}$ & $\begin{array}{c}0.002 \\
(0.002)\end{array}$ & $\begin{array}{c}0.002 \\
(0.002)\end{array}$ & $\begin{array}{c}0.002 \\
(0.003)\end{array}$ & $\begin{array}{c}0.003 \\
(0.002)\end{array}$ & $\begin{array}{c}0.003 \\
(0.003)\end{array}$ \\
\hline $\begin{array}{l}\text { Share of urban } \\
\text { population }\end{array}$ & $\begin{array}{c}-0.124 * * * \\
(0.019)\end{array}$ & $\begin{array}{c}-0.123 * * * \\
(0.019)\end{array}$ & $\begin{array}{c}-0.116^{* * *} \\
(0.018)\end{array}$ & $\begin{array}{c}-0.126 * * * \\
(0.018)\end{array}$ & $\begin{array}{c}-0.119 * * * \\
(0.019)\end{array}$ & $\begin{array}{c}-0.115^{* * *} \\
(0.019)\end{array}$ \\
\hline In-migration rate & $\begin{array}{l}-0.811 \\
(0.601)\end{array}$ & $\begin{array}{l}-2.050 * * \\
(1.018)\end{array}$ & $\begin{array}{c}-6.547 * * * \\
(1.575)\end{array}$ & $\begin{array}{c}-4.200 * * \\
(1.944)\end{array}$ & $\begin{array}{c}-0.036 * * * \\
(0.006)\end{array}$ & $\begin{array}{c}-2.645 * * * \\
(0.661)\end{array}$ \\
\hline Out-migration rate & $\begin{array}{l}1.791^{* *} \\
(0.852)\end{array}$ & $\begin{array}{c}2.928 * * \\
(1.191)\end{array}$ & $\begin{array}{c}5.385^{* * *} \\
(1.334)\end{array}$ & $\begin{array}{c}0.535 \\
(1.430)\end{array}$ & $\begin{array}{c}0.038 * * * \\
(0.007)\end{array}$ & $\begin{array}{c}2.646^{* * *} \\
(0.658)\end{array}$ \\
\hline$\rho$ & $\begin{array}{c}0.705^{* * *} \\
(0.002)\end{array}$ & $\begin{array}{c}0.704^{* * *} \\
(0.002)\end{array}$ & $\begin{array}{c}0.703 * * * \\
(0.002)\end{array}$ & $\begin{array}{c}0.705^{* * *} \\
(0.002)\end{array}$ & $\begin{array}{c}0.692 * * * \\
(0.002)\end{array}$ & $\begin{array}{c}0.699 * * * \\
(0.002)\end{array}$ \\
\hline R-squared & 0.10 & 0.11 & 0.11 & 0.10 & 0.14 & 0.12 \\
\hline
\end{tabular}

Notes: Dependent variable: education spending per pupil in 2003. Significance level: *** at $1 \%$, ** at $5 \%$, * at $10 \%$. The sample consists of observations for counties from 48 continental United States (excluding Alaska and Hawaii) and District of Columbia in 2003. Missing and incorrect data observations were dropped from the sample resulting in a total of 2952 observations. All variables are in logarithms. County in and out migration rates are computed by dividing respective migration flows during 1995-2000 by county population in 1995. By using earlier years for our migration variable we essentially lag our migration rates in order to eliminate potential simultaneous causality problem from 2003 education spending. The spatial lag model (SAM), also known as spatial autoregressive model or SAR, is estimated using maximum likelihood, where $\rho$ is the spatial lag component. Using net in-migration rates instead of in and out migration rates yield similar results. 
Table 8: Correlation Matrix for County Regression Variables

\begin{tabular}{|c|c|c|c|c|c|c|c|c|c|c|c|c|}
\hline & $\begin{array}{l}\text { Education } \\
\text { exp./pupil }\end{array}$ & Income & \begin{tabular}{|l|} 
Share of \\
people 15 \\
and \\
younger
\end{tabular} & $\begin{array}{l}\text { Share of } \\
\text { people } \\
65 \text { and } \\
\text { older }\end{array}$ & Nonwhite & $\begin{array}{l}\text { Home } \\
\text { owner }\end{array}$ & Urban & \begin{tabular}{|l|} 
In- \\
migration \\
$(55-64)$
\end{tabular} & $\begin{array}{l}\text { In- } \\
\text { migration } \\
(65-74)\end{array}$ & $\begin{array}{l}\text { In- } \\
\text { migration } \\
(75-84)\end{array}$ & $\mid \begin{array}{l}\text { In- } \\
\text { migration } \\
\left(85^{+}\right)\end{array}$ & $\begin{array}{l}\text { In- } \\
\text { migration } \\
(65+)\end{array}$ \\
\hline Education exp./pupil & 1 & 1 & & & & & & & & & & \\
\hline Income & $0.2592 *$ & 1 & 1 & & & & & & & & & \\
\hline $\begin{array}{l}\text { Share of people } 15 \\
\text { and younger }\end{array}$ & $-0.2015 *$ & -0.03 & 1 & & & & & & & & & \\
\hline $\begin{array}{l}\text { Share of people } 65 \\
\text { and older }\end{array}$ & $0.1003 *$ & $*-0.1145 *$ & * $-0.5842 *$ & 1 & & & & & & & & \\
\hline Nonwhite & $-0.1610 *$ & $*-0.0400 *$ & * $\quad 0.3114 *$ & $-0.3896 *$ & 1 & & & & & & & \\
\hline Home owner & $-0.0676^{*}$ & * $-0.2081 *$ & * $-0.1606 *$ & $0.3229 *$ & $-0.3217 *$ & 1 & & & & & & \\
\hline Urban & 0.0222 & \begin{tabular}{|l|l}
2 & $0.4231 *$
\end{tabular} & * $0.2983 *$ & $-0.4323^{*}$ & $0.3115 *$ & $-0.5696 *$ & 1 & & & & & \\
\hline In-migration (55-64) & 0.0064 & \begin{tabular}{|l|l|}
4 & $-0.0532 *$
\end{tabular} & * $-0.1688 *$ & 0.1183* & $-0.0426 *$ & $0.1793 *$ & $-0.1666 *$ & 1 & & & & \\
\hline In-migration (65-74) & -0.0076 & $6-0.0477 *$ & * $-0.1724 *$ & $0.1817 *$ & $-0.0400 *$ & $0.1642 *$ & $-0.1200 *$ & 0.8919* & 1 & 1 & & \\
\hline In-migration (75-84) & -0.0172 & $20.0457 *$ & * $-0.1161^{*}$ & $0.1332 *$ & $-0.0537 *$ & $0.0996 *$ & $-0.0405 *$ & $0.6944 *$ & $0.7234 *$ & 1 & 1 & \\
\hline In-migration (85+) & -0.0036 & 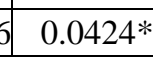 & * $-0.1273 *$ & $0.1983^{*}$ & $-0.1082 *$ & $0.0716 *$ & $-0.0898 *$ & $0.3439 *$ & $0.3477 *$ & $0.4368 *$ & 1 & \\
\hline In-migration (65+) & -0.0114 & $4 \quad-0.0030$ & $-0.1729 *$ & $0.2006 *$ & $-0.0674 *$ & $0.1495 *$ & $-0.1066 *$ & $0.8553 *$ & $0.9312 *$ & $0.8818 *$ & 0.5889* & * \\
\hline Out-migration (55-64) & $0.0670 *$ & * $0.0753^{*}$ & -0.0356 & -0.0075 & $-0.0412 *$ & -0.0020 & -0.0176 & $0.7573 *$ & $0.7029 *$ & 0.7091* & $0.3453 *$ & $0.7473 *$ \\
\hline Out-migration (65-74) & $0.0679 *$ & 0.0037 & $-0.1271 *$ & $0.1450 *$ & $-0.0902 *$ & $0.0821 *$ & $-0.0978 *$ & $0.7167 *$ & $0.6936 *$ & $0.6760 *$ & $0.3218 *$ & $0.7249 *$ \\
\hline Out-migration (75-84) & $0.0550 *$ & $*-0.0445 *$ & $-0.1965 *$ & $0.2718 *$ & $-0.1367 *$ & $0.1346 *$ & $-0.1931 *$ & $0.6618 *$ & $0.6543 *$ & $0.6143 *$ & $0.3126 *$ & $0.6777 *$ \\
\hline Out-migration $(85+)$ & 0.0095 & \begin{tabular}{|l|l}
5 & $-0.0698 *$ \\
\end{tabular} & $-0.1565^{*}$ & $0.2506 *$ & $-0.1296 *$ & $0.1203 *$ & $-0.1949 *$ & $0.3340 *$ & $0.3324 *$ & $0.3344 *$ & 0.1929* & 0.3599* \\
\hline Out-migration (65+) & $0.0595 *$ & $*-0.0382 *$ & $-0.1931 *$ & $0.2624 *$ & $-0.1417 *$ & $0.1339 *$ & $-0.1891 *$ & $0.7339 *$ & $0.7188 *$ & $0.6942 *$ & $0.3493 *$ & $0.7526^{*}$ \\
\hline
\end{tabular}

\begin{tabular}{|l|r|r|r|r|r|}
\hline & $\begin{array}{l}\text { Out- } \\
\text { migration } \\
(55-64)\end{array}$ & $\begin{array}{l}\text { Out- } \\
\text { migration } \\
(65-74)\end{array}$ & $\begin{array}{l}\text { Out- } \\
\text { migration } \\
(75-84)\end{array}$ & $\begin{array}{l}\text { Out- } \\
\text { migration } \\
(85+)\end{array}$ & $\begin{array}{l}\text { Out- } \\
\text { migration } \\
(65+)\end{array}$ \\
\hline Out-migration (55-64) & 1 & & & & \\
\hline Out-migration (65-74) & $0.7761^{*}$ & 1 & & & \\
\hline Out-migration (75-84) & $0.6629^{*}$ & $0.6591^{*}$ & 1 & & \\
\hline Out-migration (85+) & $0.3233^{*}$ & $0.3189^{*}$ & $0.4499^{*}$ & 1 & 1 \\
\hline Out-migration (65+) & $0.7606^{*}$ & $0.8687^{*}$ & $0.8819 *$ & $0.6546^{*}$ & \\
\hline
\end{tabular}

Notes: All variables are in logarithms. * denotes statistical significance at 5 percent. 


\section{References}

American Association of Retired Persons. 2004. "Political Behavior and Values Across the Generations: A Summary of Selected Findings,” AARP Strategic Issues Research, July.

Anselin, Luc. 1988. Spatial Econometrics: Methods and Models. Dordrecht: Kluwer Academic Publishers.

Baicker, Katherine. 2005. “The Spillover Effects of State Spending.” Journal of Public Economics. Vol. 89, No. 2-3: 529-544.

Bearse, P., G. Glomm, and B. Ravikumar. 2000. "On the Political Economy of Means-Tested Education Vouchers,” European Economic Review, 44: 904-915.

Brueckner, Jan and Luz Saavedra. 2001. "Do Local Governments Engage in Strategic PropertyTax Competition?” National Tax Journal. Vol. 54, No. 2: 203-29.

Bruce, Donald, D. Carroll, J. Deskins, and J. Rork. 2006. "Road to Ruin? A Spatial Analysis of State Infrastructure Spending," available at http://web.utk.edu/ dbruce/bruce.carroll.deskins.rork.roadtoruin.pdf.

Brunori, David. 2003. Local Tax Policy: A Federalist Perspective. Washington, D.C.: The Urban Institute Press.

Buettner, Theiss. 2001. "Local Business Taxation and Competition for Capital: The Choice of the Tax Rate.” Regional Science and Urban Economics. Vol. 31, No. 2-3: 215-45.

Button, James W. 1992. “A Sign of Generational Conflict: The Impact of Florida’s Aging Voters on Local School and Tax Referenda,” Social Science Quarterly 73 (4): 786-797.

Button, James W. and Walter A. Rosenbaum. 1989. "Seeing Gray: School Bond Issues and the Aging in Florida,” Research on Aging 11 (2): 158-173.

Case, Anne. 1993. "Interstate Tax Competition After TRA 86." Journal of Policy Analysis and Management. Vol. 12, No. 1: 136-48.

Case, Anne, James Hines and Harvey Rosen. 1993. "Budget Spillovers and Fiscal Policy Interdependence.” Journal of Public Economics. Vol. 52, No. 3: 285-307.

Cebula, Richard J. 1990. "A Brief Empirical Note on the Tiebout Hypothesis and State Income Tax Policies." Public Choice. Vol. 67, No. 1: 87-9.

Cliff, A., Ord, J. 1981. Spatial Processes, Models, and Applications. London: Pion.

Conway, Karen S. and Andrew J. Houtenville. 1998. "Do the Elderly 'Vote with Their Feet'?” Public Choice 97 (4): 663-685.

Conway, Karen S. and Andrew J. Houtenville. 2001. "Elderly Migration and State Fiscal Policy: 
Evidence from the 1990 Census Migration Flows,” National Tax Journal 54 (1): 103123.

Conway, Karen Smith and Andrew J. Houtenville. 2003. "Out with the Old, In with the Old: A Closer Look at Younger versus Older Elderly Migration.” Social Science Quarterly 84 No 2: 309-28.

Conway, Karen S. and Jonathan C. Rork. 2004. "Diagnosis Murder: The Death of State Death Taxes,” Economic Inquiry 42 (4): 537-559.

Conway, Karen Smith and Jonathan C. Rork. 2006. “State 'Death’ Taxes and Elderly Migration — The Chicken or the Egg?” National Tax Journal, Volume LIX, No. 1, available at http://pubpages.unh.edu/ ksconway/NTJ_Conway_Rork_Finalv.pdf.

Deller, Steven C. and Norman Walzer. 1993. "The Effects of an Aging Rural Population on the Financing of Rural Public Education,” Journal of Research in Rural Education 9 (2): 104-114.

Elhorst, J. Paul. 2003. “Specification and Estimation of Spatial Panel Data Models.” International Regional Science Review, 26 (3): 244-268.

Farnham, Martin and Purvi Sevak. 2002. "Local Fiscal Policy and Retiree Migration: Evidence from the Health and Retirement Study,” manuscript.

Figlio, David, Koplin, Van W. and William Reid. 1999. “Do States Play Welfare Games?” Journal of Urban Economics. Vol. 46, No. 3: 437-54.

Fournier, Gary M., David W. Rasmussen, and William J. Serow. 1988. "Elderly Migration as a Response to Economic Incentives.” Social Science Quarterly 69 No.2: 245-260.

Gale, L.R. and W.C. Heath. 2000. "Elderly Internal Migration in the United States Revisted," Public Finance Review.

Gradstein, Mark and Michael Kaganovich. 2004. “Aging Population and Education Finance,” Journal of Public Economics 88 (12): 2469-2485.

Harris, Amy R., William N. Evans and Robert M. Schwab. 2001. "Education Spending in an Aging America,” Journal of Public Economics 81 (3): 449-472.

He, Wan and Jason P. Schachter. 2003. "Internal Migration of the Older Population: 1995 to 2000” Census 2000 Special Reports CENSR-10, U.S. Department of Commerce, U.S. Census Bureau.

Heyndels, Bruno and Jef Vuchelen. 1998. "Tax Mimicking Among Belgian Municipalities." National Tax Journal. Vol. 51, No. 1: 89-101.

Holtz-Eakin, Douglas J., Mary E. Lovely and Mehmet S. Tosun. 2004. “Generational Conflict, Fiscal Policy and Economic Growth,” Journal of Macroeconomics 26 (1): 1-23. 
Ladd, Helen F. and Sheila E. Murray. 2001. "Intergenerational Conflict Reconsidered: County Demographic Structure and the Demand for Public Education," Economics of Education Review 20 (4): 343-357.

LeSage J. P. (1999). Applied Econometrics using MATLAB. Manuscript, Dept. of Economics, University of Toronto.

Newbold, K. B. 1996. Determinants of elderly interstate migration in the United States, 19851990. Research on Aging, 18,451-476.

Poterba, James M. 1997. "Demographic Structure and the Political Economy of Public Education,” Journal of Policy Analysis and Management 16 (1): 48-66.

Poterba, James M. 1998. "Demographic Change, Intergenerational Linkages, and Public Education,” American Economic Review 88 (2): 315-320.

Razin, A., E. Sadka and P. Swagel. 2002. "The Aging Population and the Size of the Welfare State,” Journal of Political Economy 110 (4): 900-918.

Reeder, Richard J. and Nina L. Glasgow. 1990. "Nonmetro Retirement Counties’ Strengths and Weaknesses,” Rural Development Perspectives (February): 12-17.

Revelli, Federico. 2001. "Spatial Patterns in Local Taxation: Tax Mimicking or Error Mimicking?” Applied Economics. Vol. 33, No. 9: 1101-07.

Rork, Jonathan. 2003. “Coveting Thy Neighbors’ Taxation.” National Tax Journal. Vol. 56, No. 4: $775-787$.

Rosenbaum, Walter A. and James W. Button. 1989. "Is There Gray Peril?: Retirement Politics in Florida,” The Gerontologist 29 (3): 300-306.

Saavedra, Luz. 2000. “A Model of Welfare Competition with Evidence from AFDC.” Journal of Urban Economics. Vol. 47, No. 2: 248-79.

Serow, William J., Douglas A. Charity, Gary M. Fournier, and David W. Rasmussen. 1986. "Cost of Living Differentials and Elderly Interstate Migration.” Research on Aging 8 No. 2: 317-327.

Slavov, Sita Nataraj. 2006. "Age Bias in Fiscal Policy: Why Does the Political Process Favor the Elderly?," Topics in Theoretical Economics: Vol. 6 : Iss. 1, Article 11, available at http://www.bepress.com/bejte/topics/vol6/iss1/art11.

Tosun, Mehmet S. 2008. "Endogenous Fiscal Policy and Capital Market Transmissions in the Presence of Demographic Shocks.” Journal of Economic Dynamics and Control 32 (6): 2031-2060.

Tosun, Mehmet S. 2005. “Global Aging and Fiscal Policy with International Labor Mobility: A 
Political Economy Perspective,” IMF Working Paper 05/140. Washington, D.C.: IMF.

Tosun, Mehmet S. 2003. "Population Aging and Economic Growth: Political Economy and Open Economy Effects,”2003 (December). Economics Letters 81 (3): 291-296.

Voss, P., Gunderson, R., Manchin, R. 1988. Death taxes and elderly interstate migration. Research on Aging, 10,420-450. 